Volume 12

Issue 2 Images And Collective Violence:

Function, Use And Memory

$10-2018$

\title{
Book Review: Rwanda Genocide Stories: Fiction After 1994
}

Rafiki Ubaldo

Temples of Memory

Follow this and additional works at: https://digitalcommons.usf.edu/gsp

\section{Recommended Citation}

Ubaldo, Rafiki (2018) "Book Review: Rwanda Genocide Stories: Fiction After 1994," Genocide Studies and Prevention: An International Journal: Vol. 12: Iss. 2: 193-196.

DOI:

https://doi.org/10.5038/1911-9933.12.2.1583

Available at: https://digitalcommons.usf.edu/gsp/vol12/iss2/16

This Book Review is brought to you for free and open access by the Open Access Journals at Digital Commons @ University of South Florida. It has been accepted for inclusion in Genocide Studies and Prevention: An International Journal by an authorized editor of Digital Commons @ University of South Florida. For more information, please contact digitalcommons@usf.edu. 


\title{
Book Review: Rwanda Genocide Stories: Fiction After 1994
}

\author{
Rafiki Ubaldo \\ Temples of Memory
}

Rwanda Genocide Stories: Fiction After 1994

Nicki Hitchcott

Liverpool, Liverpool University Press, 2015

229 Pages; Price: $£ 80.00$ Cloth

Reviewed by Rafiki Ubaldo

Temples of Memory

"How do writers who did not live through the genocide tell the stories of those who did? How do their stories differ from those of the Rwandan people who experienced it first-hand? What are the ethical implications of telling other people's stories of genocide? Or [...] what happens when a writer who is not a survivor or a perpetrator retells, and revises, a survivor or a perpetrator's story?"1 These are some of the questions Nicki Hitchcott seeks to answer through Rwanda Genocide Stories: Fiction After 1994, a study "of the ways in which African writers tell the story of the genocide" of 1994 in Rwanda. ${ }^{2}$

While non-Rwandan African writers are insiders to the story of the African continent in general, they nonetheless remain geographical outsiders to the lived experiences of the genocide that decimated the Tutsi of Rwanda. Thus, Rwanda Genocide Stories compares two sets of texts, namely the eleven works of Rwandan authors who lived in Rwanda at the time of the genocide, and the works of African authors, including two Rwandans who lived outside the country during the genocide. The authors who resided outside Rwanda during the genocide travelled to Rwanda in 1998 to engage in a literary reflection about what happened there in 1994. This group was later known as 'Rwanda: Ecrire par devoir de mémoire' (Writing with a duty to remember) group. They are natives of Senegal, Chad, Burkina Faso, Guinea, Cote d'Ivoire, Djibouti, Kenya, and Rwanda.

The importance of Rwanda Genocide Stories probably resides in its particular attention to the group of Rwandan authors who have not received the same international exposure as the 'Rwanda: Ecrire par devoir de mémoire' group. It goes without saying that all the texts Hitchcott compares in this book were written in French.

Rwanda Genocide Stories' analysis centres around the authors' positions vis-à-vis the genocide, and the subject positions of victim, perpetrator, witness, and survivor. These subject positions are, the book suggests, salient points of sharp discussions about identities in post-genocide Rwanda. In practice, the book looks at how a work of fiction constructs the subject-positions of victim, perpetrator, survivor, and witness. Also, it looks at how the authors of fiction proceed in taking sides vis-a-vis these subject positions; and how the academic market positions itself towards the different stands the authors adopt in relation to these subject questions.

The 'Rwanda: Ecrire par devoir de mémoire' group of authors is viewed here as ambivalent and literary dark tourists. Their inspiration comes mostly from the genocide memorials they visited during their stay in Rwanda. Even though the authors were travelling with a specific purpose, they nonetheless did dark tourism, namely trips "to a range of sites or tourist attractions associated with death and disaster." ${ }^{3}$ The descriptions of the horror in the memorials challenged the literary dark tourists emotionally and morally, which led to ambivalent positions in writing about the killings of 1994. However, the authors realised that the story of 1994 in Rwanda is an extreme miniature of the suffering the entire continent of Africa. It is, therefore, and as Hitchcott puts it, "this tension between insider and outsider status that generates anxiety in the texts" written by 'Rwanda: Ecrire

${ }^{1}$ Nicki Hitchcott, Rwanda Genocide Stories: Fiction After 1994 (Liverpool: Liverpool University Press, 2015), 15.

${ }^{2}$ Ibid., 15.

${ }^{3}$ Ibid., 60.

Rafiki Ubaldo. "Book Review: Rwanda Genocide Stories: Fiction After 1994" Genocide Studies and Prevention 12, 2(2018): 193-196. (02018 Genocide Studies and Prevention.

https://doi.org/10.5038/1911-9933.12.2.1583 
par devoir de mémoire group'. ${ }^{4}$ This ambivalence, Hitchcott argues, that compels us the readers of this dark tourism texts "to reflect on how to position ourselves as self-conscious and responsible tourists." ${ }^{5}$

As for the Rwandan authors who lived abroad in 1994, the geographical distance puts them into the category of insiders-outsiders to the genocide story. These authors experienced genocide second-hand, and their writing depends on testimonies of family members, survivors and other witnesses. This is contrary to the group of the eleven Rwandan authors who lived in the country at the time of the genocide, and who are primarily regarded as witnesses. Some of them are survivors who experienced the genocide first-hand. Others are Rwandan Hutus who lived in the country, but who were not the target of the genocide. These Hutus are also witnesses with an insider's story. But regardless of whether or not they lived in Rwandan in 1994, all the Rwandan authors are concerned with "documenting and remembering the truth about what happened in 1994." 6 However the task of documenting and remembering genocide becomes complicated since, and as time pass, the survivors are more and more reluctant to talk about the stories of their survival because of the painful memories such an exercise brings back.

Hitchcott observes that the texts by Rwandans who witnessed the genocide second-hand and those who saw it first-hand do share "an emphasis on the ambivalent position of the witness." ${ }^{17}$ This ambivalence is probably due to a certain awareness that the major part of the story of the genocide vanished with the victims. And "those who remain alive cannot know or do not want to know," partly because they are faced with a dilemma of testifying "to that which they did not experience." 8 But all authors of fiction are secondary witnesses of the events, "since fiction necessarily increase the distance between the narrative and the event." ${ }^{\prime 9}$ However, Hitchcott reminds that the proximity to or the distance from the genocide itself influences the way authors write and how audiences receive their work.

In retrospect, the survivors of the genocide feel guilty of having survived while many others did not. Furthermore, they are like an unwanted reminder of a horrible past many people would like to forget as they build a post-genocide society. And Rwandan authors who survived the genocide would rather discretely distance themselves from a stigmatised identity. As for Hutu authors, it is difficult to associate with the survivor's identity since the official terminology of the genocide, that is the 'Genocide against the Tutsi,' only names the Tutsi explicitly. That said, all the works analysed in Rwanda Genocide Stories aim to recognise the place of the survivors whose contributions to rebuilding the country are otherwise almost invisible.

These works are also engaged in remembering "the individuality of victims and reminding the world of the humanity of those who died."10 In engaging with the victim theme, the authors question collective and national memorial commemorations that depersonalise the victims. Also, the authors mock the debates about the exact number of the genocide victims, insisting instead on beautifying individual victims of the genocide to achieve a re-humanised representation of all the victims of the genocide.

Almost all the works analysed in this book are against a homogenisation of the dead, which leads to a "commodification of death that [...] has become an important component of the tourist industry in present-day Rwanda."11 Hitchcott comes to the overreaching conclusion that while the genocide novelists are faced with many challenged of telling the story of an unspeakably horrible event, they are nevertheless using fiction "as means of remembering the individuality of victims

\footnotetext{
${ }^{4}$ Ibid., 65 .

${ }^{5}$ Ibid., 79.

${ }^{6}$ Ibid., 80 .

${ }^{7}$ Ibid., 88.

${ }^{8}$ Ibid., 91.

${ }^{9}$ Ibid., 103.

${ }^{10}$ Ibid., 141.

${ }^{11}$ Ibid., 141.
} 
and reminding the world of the humanity of those who died."12

There is also the genocide perpetrators category. Hitchcott informs that "many authors draw [the perpetrators] as unremarkable individuals, reflecting what James Waller, following Hannah Arendt, emphasises as the 'ordinariness' of those who commit acts of 'extraordinary human evil'."13 The friendship between many perpetrators friends and relatives of their victims complicates the ordinariness of the perpetrator, and blurs the categories of perpetrator and victim, since, each in their ways, are trying to recover from the trauma the genocide causes them. ${ }^{14}$

However, the exercise of "imagining the humanity of perpetrators who have committed acts of such unimaginable horror is a risky business" puts the reader and the author in front of a challenging moral dilemma of "mitigating [the perpetrator's] crimes and negating the experiences of the victims." ${ }^{15}$ Nevertheless, Hitchcott acknowledges the importance of those work of genocide fiction that emphasise the social importance of the perpetrators' testimonies of confession. Also, Hitchcott notices a moral hierarchy in some genocide fiction where the authors are "more shocked by the acts of the female than male perpetrators, ${ }^{16}$ because they perceive motherhood as a natural shield that that prevents women from committing atrocities.

Most importantly, however, Hitchcott remarks that the fiction of the genocide in Rwanda faces a generalisation that sees the "Tutsi as the innocent victims and the Hutu as the bloodstained perpetrators." 17 Furthermore, she observes that while Rwandan authors keep their focus on the local, individual perpetrator characters, the fiction of non-Rwandan authors "reveals a strong desire to implicate the international community, particularly France, in the genocide in Rwanda. Those writers from outside Rwanda who participated in 'Ecrire par devoir de mémoire' mission tend to project their guilt about the world's failure to intervene into their texts." 18

One of the many strengths of Hitchcott's analysis of the genocide fiction is its ability to reflect the different facets of Rwanda's genocide story in ways few scholarly works would succeed. In some works, the characters are children from a family where one of the parents is Hutu and the other parent is Tutsi. In other cases, the characters are Tutsi who changed their identity cards, and became Hutu in the years before the genocide. In other insistences, and to highlight the ambiguity of ethnic identifications in Rwanda, the reader of genocide fiction is left second-guessing the identity of the character, until towards the end the ethnic belonging is finally mentioned as a detail of little importance. ${ }^{19}$ Furthermore, Hitchcott "identified the ways in which readers are compelled to re-evaluate their knowledge of Rwanda and take an active role in commemorative processes: as self-critical tourists, ethical witnesses, judges or culpable bystanders," ${ }^{20}$ thus knowing more about the genocide.

However, there are arguably more existential questions to discuss in the genocide fiction than providing detailed descriptive analyses such as Hitchcott's. For example, the question of why "spaces in which protection, shelter, or the care of the young are abruptly inverted into their utter polar opposite, death and destruction" is crucial, considering the meanings and the temporality of spaces of worship or learning, such as churches and school where people were exterminated in 1994. ${ }^{21}$ The annihilation of the social meanings of such spaces and the temporality of rituals performed in these spaces in times of normality compel writers to deal with the question: "How can you envisage the future here? What future?"22 Indeed, how to imagine a future in which both

\footnotetext{
${ }^{12}$ Ibid., 141.

${ }^{13}$ Ibid., 163.

${ }^{14}$ Ibid., 170.

${ }^{15}$ Ibid., 173.

${ }^{16}$ Ibid., 178.

${ }^{17}$ Ibid., 179.

${ }^{18}$ Ibid., 187.

${ }^{19}$ Ibid., 181.

${ }^{20}$ Ibid., 191.

${ }^{21}$ Russel West-Parlov, 2014, "Regardez la vie reprendre': Futurity" in Véronique Tadjo's L'Ombre d'Imana / The Shadow of Imana, in Tydskrif vir Letterkunde, 51 (2),114.

${ }^{22}$ Ibid., 114.
} 
the survivors and the perpetrators are re-humanised in the very spaces where the negation and the annihilation of human life took place? This question and other reflections on themes such as life and death, love and empathy in the context of marital relationships and parenthood, to name but a few universalist themes, should be at the centre of the genocide fiction. Such an approach would help writers overcome a genocide narrative that evolves around the so-called eruption of centuries old ethnic hatred between the Hutu and the Tutsi.

That said, the wounds of the genocide are still fresh in Rwanda. This also makes it difficult to engage in dispassionate analysis of the genocide fiction. Furthermore, Rwanda's history of violence and the multitude of the actors involved in the genocide of 1994 complicate the task of going beyond the usual portrait of Africa as a continent of incomprehensible but frequent tribal violence. It goes without saying that it is a daunting mission to analyse the work of African writers engaged in dignifying fellow Africans killed in the last genocide of the $20^{\text {th }}$ century.

And a more complicated task is to grasp creative works that re-humanise the perpetrators of genocide. In such an exercise, accuracy demands meticulous analysis, and concise descriptions such as the ones Hitchcott provides in her book. ${ }^{23}$ She remarkably completed a challenging task. After reading this book, one gets the understanding that genocide fiction is about learning the ways to cherish and to beautify life, again, after genocide.

${ }^{23}$ The abundance of details and lengthy descriptions in the analyses of genocide fiction is not unique to Hitchcott. Nyirubugara, a Rwandan-Dutch scholar, struggles with the intricacies of explaining the realities or the perceptions behind the subject positions in genocide fiction he analyses. See Nyirubugara Oliver, Novels of Genocide: Remembering and Forgetting the Ethnic Other in Fictional Rwanda, (Leiden: Sidestone Press, 2017), 187. 